Egypt. Acad. J. Biolog. Sci., 13(2):323-331 (2020)

Egyptian Academic Journal of Biological Sciences

A. Entomology

ISSN 1687- 8809

http://eajbsa.journals.ekb.eg/

\title{
Impact of Foliar Application by Salicylic Acid on Some Pea Cultivars and Their Response to Insect Infestation
}

El-Dakkak, A.A.A. ${ }^{1}$, El-Solimany, E.A ${ }^{2}$ and Hassan, A.T. ${ }^{2}$

1-Horticultural Research Institute, Agricultural Research Centre, Giza, Egypt.

2-Plant Protection Research Institute, Agricultural Research Centre, Dokki, Giza, Egypt.

\begin{abstract}
ARTICLE INFO
Article History

Received:29/4/2020

Accepted:30/6/2020

Keywords:

Pisum sativum,

Aphis craccivora,

Thrips tabaci,

Liriomyza trifolii,

cultivars, and

salicylic acid.

\section{ABSTRACT}

The present study was conducted out to investigate the effect of foliar application of five pea cultivars (Entesar 1, Goara, Line 1, Line 11 and Line 14) with salicylic acid (SA) on infestation by Aphis craccivora (Koch.), Thrips tabaci Lindeman and Liriomyza trifolii Burg. during 2018/2019 and 2019/2020 winter seasons at Sohag Governorate. Also, the effect of SA application on the growth, yield, and some yield components of pea was included. Data revealed that the foliar application with SA at 200ppm and 100ppm reduced A. craccivora, T. tabaci, and L. trifolii (mines) infestations by about $50 \%$ and $30 \%$, respectively, compared with control in both seasons. Also, plant height, the number of pods/ plant, weight, total green pods yield/ plant, and total yield/ Feddan were increased by the two SA treatments comparing to control in both seasons. The five pea cultivars varied significantly in their susceptibility to the three studied pests and in horticultural characters in both seasons. The interaction between pea varieties and SA treatments was discussed.
\end{abstract}

\section{INTRODUCTION}

Pea, Pisum sativum L. (Fam: Fabaceae) is one of the most important leguminous vegetable crops in Egypt for local consumption and exportation. Pea cultivates during winter season for green pods which contain a great amount of protein and carbohydrates (Hussein $e t$ al. 2006). In Egypt, the pea is subjected to attack by a number of insect pests include Aphis craccivora (Koch.), Liriomyza trifolii Burg., Thrips tabaci Lindeman, (El-Solimany, 2008 and Hassan et al., 2016). Insect infestation causes great yield damage, which can result in greater than $50 \%$ yield reduction (El-Roby, 2016). Induced resistance has been defined as the " qualitative or quantitative enhancement of a plant's defense mechanisms against pests in response to extrinsic physical or chemical stimuli." (Kogan and Paxton, 1983). The use of elicitors of plant resistance like salicylic acid as a mean of controlling insect pests in agriculture have proposed by many investigators (El-Khawas, 2012; Mahmoud and Mahfouz, 2015; Elhamahmy et al., 2016 and Mony et al., 2017). In addition to the reduction of insect pests population infesting pea, foliar application with salicylic acid can improve plant growth and yield (Murtaza et al., 2007; Gad El-Hak et al., 2012; Ratushnyak et al., 2012 and ElSaadony et al., 2017). Thus, the present investigation was conducted to assess the infestation level of aphid thrips and leafminer in pea due to the application of salicylic acid on five pea cultivars and their effects on the growth, yield and yield components of pea. 


\section{MATERIALS AND METHODS}

The present study was executed at The Experimental Farm of Shandweel Agricultural Research Station, Sohag Governorate, Egypt during the winter seasons of 2018/2019 and 2019/2020. The study included 15 treatments, which were the combination of five pea cultivars and three foliar application treatments with salicylic acid. Pea cultivars used were Entesar 1, Goara, Line 11, Line 1, and Line 14. Salicylic acid was applied at $200 \mathrm{ppm}$ and $100 \mathrm{ppm}$ in addition to control (water only). The previous treatments were arranged in a splitplot in a complete randomized block design with three replicates. The main plots were used for pea cultivars; however, the foliar applications of salicylic acid were randomly arranged in the subplots. Each experimental unit was 1/400 fedddan $\left(10.5 \mathrm{~m}^{2}\right)$ including 5 rows, each of $3.5 \mathrm{~m}$ length, and $70 \mathrm{~cm}$ width. Sowing was done on $20^{\text {th }}$ October in both seasons by sowing three seeds per hill at $35 \mathrm{~cm}$ intervals. Growing plants were thinned into one plant/ hill. Conventional agricultural practices were performed and no insecticidal treatments were used during the whole study period. Pea plots were sprayed with Salicylic acid dissolved in a few drops of ethanol and then dispersed in water to give required rates. Plants were sprayed after 25 days of sowing by one-week interval for three times using hydraulic sprayer (control plots applied only with water).

\section{Insect Data:}

The experiment was left for natural infestation, data were recorded at the weekly interval, from first plant emergence (about 15 days from sowing) till crop harvest (the last week of January). In the early morning, 10 randomly leaves per plot were examined in the field and the number of thrips was recorded. Concerning aphid and leafminer, samples consisted of 10 leaves were randomly chosen from three levels, i.e., lower, middle, and upper of pea plants, transferred in polyethylene bags to the laboratory, and the numbers of aphid and mines due to leafminers were counted.

\section{Horticultural Data:}

Plant Height: At the end of each season, samples consisted of 10 plants were randomly taken from each plot to determine the plant height $(\mathrm{cm})$.

Green Pod Yield and its Components: samples consisted of 10 plants were randomly taken from each plot to determine the number of fresh pods/ plant, the average fresh pod weight $(\mathrm{g})$ and total yield of green pods/ plant (g), also, the green pod yield/fed was calculated in both seasons.

\section{Statistical Analysis:}

Statistical analysis was conducted by using one - way analysis of variance. ' $F$ ' test used to evaluate the significance of the difference between pea cultivars, salicylic acid treatments, and their interaction. The Duncan's Multiple Range Test at $\mathrm{P}=5 \%$ was used to separate the means (Gomez and Gomez, 1984).

\section{RESULTS AND DISCUSSION}

\section{Insect Pests:}

Data in Table (1) revealed that the differences between pea cultivars and between SA treatments were significant in both seasons of the study for the three studied pests. Also, the interaction between pea cultivars and SA treatments was significant in both seasons for thrips and leafminers, however, no interaction was found in both seasons in the case of aphid (Table 2). It is clear that the differences between SA treatments varied according to the pea genotype in both seasons. 
Table 1: Effect of pea cultivars and foliar spray with salicylic acid on infestation with Aphis craccivora, Thrips tabaci, and Liriomyza trifolii during 2018/2019 and 2019/2020 seasons.

\begin{tabular}{|c|c|c|c|c|c|c|}
\hline \multirow{3}{*}{ Main effect } & \multicolumn{6}{|c|}{ Mean number/ 10 leaves } \\
\hline & \multicolumn{2}{|c|}{ Aphis craccivora } & \multicolumn{2}{|c|}{ Thrips tabaci } & \multicolumn{2}{|c|}{ Liriomyza trifolii } \\
\hline & $\begin{array}{c}2018 / 2019 \\
\text { season }\end{array}$ & $\begin{array}{c}2019 / 2020 \\
\text { season }\end{array}$ & $\begin{array}{c}2018 / 2019 \\
\text { season }\end{array}$ & $\begin{array}{c}2019 / 2020 \\
\text { season }\end{array}$ & $\begin{array}{c}2018 / 2019 \\
\text { season }\end{array}$ & $\begin{array}{c}2019 / 2020 \\
\text { season }\end{array}$ \\
\hline \multicolumn{7}{|l|}{ Pea variety } \\
\hline Entesar 1 & $27.85 \mathrm{c}$ & $27.96 \mathbf{b}$ & $7.65 \mathrm{a}$ & $8.16 \mathbf{a}$ & $4.29 \mathrm{~b}$ & $5.93 \mathbf{b}$ \\
\hline Goara & $38.87 \mathbf{b}$ & $35.65 \mathbf{b}$ & $4.85 \mathrm{~b}$ & $4.74 \mathrm{~b}$ & $4.21 \mathrm{~b}$ & $5.02 \mathrm{~b}$ \\
\hline Line 11 & $44.53 \mathrm{~b}$ & $49.38 \mathbf{b}$ & $5.07 \mathrm{~b}$ & $5.08 \mathrm{~b}$ & $6.03 \mathrm{a}$ & $6.36 \mathbf{a b}$ \\
\hline Line 1 & $70.47 \mathrm{a}$ & $89.09 \mathrm{a}$ & $7.50 \mathrm{a}$ & $8.03 \mathrm{a}$ & $6.31 \mathrm{a}$ & $7.93 \mathrm{a}$ \\
\hline Line 14 & $43.03 \mathbf{b}$ & $47.57 \mathrm{~b}$ & $4.56 \mathrm{~b}$ & $4.65 \mathrm{~b}$ & $5.98 \mathrm{a}$ & $6.08 \mathrm{~b}$ \\
\hline F. value & 105.03 & 29.68 & 68.73 & 139.53 & 107.88 & 14.30 \\
\hline \multicolumn{7}{|l|}{ SA treatment } \\
\hline SA 200 & $31.53 \mathbf{b}$ & $32.46 \mathbf{b}$ & $3.94 \mathrm{c}$ & $4.31 \mathrm{c}$ & $3.79 \mathrm{c}$ & $4.54 \mathrm{~b}$ \\
\hline SA 100 & $41.54 \mathbf{b}$ & $47.59 \mathrm{~b}$ & $5.96 \mathrm{~b}$ & $5.76 \mathbf{b}$ & $4.77 \mathrm{~b}$ & $5.42 \mathrm{~b}$ \\
\hline Control & $61.79 \mathrm{a}$ & $69.73 \mathbf{a}$ & $7.87 \mathbf{a}$ & $8.32 \mathbf{a}$ & $7.53 \mathbf{a}$ & $8.83 \mathbf{a}$ \\
\hline F. value & 44.36 & 33.62 & 136.44 & 160.75 & 249.29 & 91.82 \\
\hline
\end{tabular}

Means in each column followed by the same letter are not significantly different at the $5 \%$ level according to Duncan ,s Multiple Range Test.

Table 2: Effect of the interaction between pea cultivars and spraying with salicylic acid on infestation with Aphis craccivora, Thrips tabaci, and Liriomyza trifolii during 2018/2019 and 2019/2020 seasons.

\begin{tabular}{|c|c|c|c|c|c|c|c|}
\hline \multirow{3}{*}{$\begin{array}{c}\text { Pea } \\
\text { variety }\end{array}$} & \multirow{3}{*}{$\begin{array}{l}\text { Salicylic } \\
\text { treatment }\end{array}$} & \multicolumn{6}{|c|}{ Mean number/ 10 leaves } \\
\hline & & \multicolumn{2}{|c|}{ Aphis craccivora } & \multicolumn{2}{|c|}{ Thrips tabaci } & \multicolumn{2}{|c|}{ Liriomyza trifolii } \\
\hline & & $\begin{array}{c}2018 / 2019 \\
\text { season }\end{array}$ & $\begin{array}{c}2019 / 2020 \\
\text { season }\end{array}$ & $\begin{array}{c}2018 / 2019 \\
\text { season }\end{array}$ & $\begin{array}{c}2019 / 2020 \\
\text { season }\end{array}$ & $\begin{array}{c}2018 / 2019 \\
\text { season }\end{array}$ & $\begin{array}{c}2019 / 2020 \\
\text { season }\end{array}$ \\
\hline \multirow{3}{*}{$\begin{array}{c}\text { Entesar } \\
1\end{array}$} & SA 200 & $16.10 \mathbf{f}$ & $13.64 \mathrm{~g}$ & $4.51 \mathrm{gh}$ & $4.77 \mathrm{e}$ & $2.13 \mathrm{~h}$ & $3.21 \mathrm{~g}$ \\
\hline & SA 100 & $19.33 \mathbf{f}$ & $16.21 \mathrm{~g}$ & $8.03 \mathbf{b}$ & $8.26 \mathrm{c}$ & $3.77 \mathrm{fg}$ & $4.82 \mathrm{fg}$ \\
\hline & Control & 48.10 cd & 54.03 cdef & $10.41 \mathrm{a}$ & $11.46 \mathbf{a}$ & $6.97 \mathbf{b}$ & $9.77 \mathbf{a}$ \\
\hline \multirow{3}{*}{ Goara } & SA 200 & 24.56 ef & $22.08 \mathrm{~g}$ & $2.69 \mathbf{i}$ & $3.28 \mathrm{fg}$ & $3.31 \mathrm{~g}$ & $3.85 \mathrm{fg}$ \\
\hline & SA 100 & 37.46 de & 36.49 defg & $4.90 \mathrm{fg}$ & 4.45 ef & $3.56 \mathrm{~g}$ & $3.92 \mathbf{f g}$ \\
\hline & Control & 54.59 bcd & 48.38 cdef & 6.97 bcd & $6.49 \mathrm{~d}$ & $5.77 \mathrm{c}$ & $7.28 \mathrm{~cd}$ \\
\hline \multirow{3}{*}{ Line 11} & SA 200 & 30.03 ef & $31.67 \mathrm{fg}$ & $3.67 \mathbf{~ h i}$ & $3.72 \mathrm{efg}$ & 4.92 cde & $5.05 f$ \\
\hline & SA 100 & $39.68 \mathrm{de}$ & 46.97 cdef & $5.10 \mathrm{fg}$ & $4.18 \mathrm{efg}$ & $5.56 \mathrm{c}$ & 5.41 ef \\
\hline & Control & 63.89 bc & 69.49 bc & 6.44 cde & $7.33 \mathrm{~cd}$ & $7.59 \mathbf{b}$ & 8.62 abc \\
\hline \multirow{3}{*}{ Line 1} & SA 200 & $49.62 \mathrm{~cd}$ & $60.33 \mathrm{~cd}$ & 5.74 ef & $6.74 \mathrm{~d}$ & $4.08 \mathrm{efg}$ & $6.90 \mathrm{de}$ \\
\hline & SA 100 & $69.77 \mathrm{~b}$ & $88.54 \mathbf{b}$ & 7.26 bc & $7.51 \mathrm{~cd}$ & $5.36 \mathrm{~cd}$ & 7.77 bcd \\
\hline & Control & $92.03 \mathrm{a}$ & $118.38 \mathbf{a}$ & $9.49 \mathbf{a}$ & 9.82 b & $9.49 \mathbf{a}$ & $9.13 \mathrm{ab}$ \\
\hline \multirow{3}{*}{ Line 14} & SA 200 & 37.33 de & 34.56 efg & $3.10 \mathbf{i}$ & $3.05 \mathrm{~g}$ & 4.54 def & $3.72 \mathbf{f g}$ \\
\hline & SA 100 & $41.44 \mathrm{de}$ & 49.77 cdef & $4.51 \mathrm{gh}$ & 4.41 ef & $5.59 \mathrm{c}$ & $5.15 \mathbf{f}$ \\
\hline & Control & 50.33 cd & 58.38 cde & 6.05 def & $6.49 \mathrm{~d}$ & $7.82 \mathbf{b}$ & $9.36 \mathbf{a b}$ \\
\hline \multicolumn{2}{|c|}{ F. value } & 1.37 & 1.33 & 3.06 & 5.28 & 6.30 & 3.21 \\
\hline
\end{tabular}

Means of among of each column followed by the same letter are not significantly different at the $5 \%$ level according to Duncan, s Multiple Range Test. 


\section{1- Aphis craccivora:}

Data in (Table 1) showed that the highest infestation observed in Line 1 with 70.47 and 89.09 aphids/ ten leaves in the two seasons, respectively, however, lowest aphid number recorded in Entesar 1 with 27.85 and 27.96 aphids/ ten leaves in the two seasons, respectively, followed insignificantly by Goara, Line 11 and Line 14 in the second season.

The foliar application with SA at 200ppm and 100ppm reduced aphid infestation by about $50 \%$ and $30 \%$, respectively, compared with control in both seasons. It is clear that the two SA concentrations did not differ significantly in both seasons. SA at 200ppm, 100ppm, and control recorded 31.53, 41.54, and 61.79 aphids/ ten leaves, respectively, in the first season, and 32.46, 47.59, and 69.73 aphids/ ten leaves, respectively, in the second season.

For the combination between SA treatments and pea cultivars, the lowest aphid infestation was recorded in Entesar $1 \mathrm{x}$ SA at 200ppm with 16.10 and 13.64 aphids/ ten leaves in the two seasons, respectively, followed insignificantly by Entesar $1 \mathrm{x}$ SA at 100ppm, Goara x SA at 200ppm and Line $11 \mathrm{x}$ SA at 200ppm in both seasons, and by Goara $\mathrm{x}$ SA at 100ppm and Line $14 \mathrm{x} \mathrm{SA}$ at 200ppm in the second season only. While, the highest one recorded in Line 1 x control with 92.03 and 118.38 aphids/ ten leaves in the two seasons, respectively. Our results are widely in agreement with the previous studies, the spraying of SA was reported to be an effective elicitor to diminish aphid numbers on wheat (Mahmoud and Mahfouz, 2015), on canola (Elhamahmy et al., 2016), and on mustard (Mony et al., 2017).

\section{2- Thrips tabaci:}

Depending on the mean number of thrips per 10 leaves, the five pea cultivars arranged in two significant groups. The lowest infested included Goara, Line 11 and Line 14 with 4.85, 5.07, and 4.56 thrips/ ten leaves, respectively in the first season, and 4.74, 5.08, and 4.65 thrips/ ten leaves, respectively in the second season. However, the highest infested included Entesar 1 and Line 1 with 7.65 and 7.50 thrips/ ten leaves, respectively in the first season, and with 8.16 and 8.03 thrips/ ten leaves, respectively in the second season.

The results proved that the foliar application with SA reduced the mean number of thrips comparing to control by $50 \%$ and $30 \%$ at $200 \mathrm{ppm}$ and $100 \mathrm{ppm}$, respectively, in the two seasons. SA at 200ppm, 100ppm, and control recorded 3.94, 5.96, and 7.87 thrips/ ten leaves, respectively, in the first season, and 4.31, 5.76, and 8.32 thrips/ ten leaves, respectively, in the second season.

Concerning the interaction between pea cultivars and SA treatments, it is clear that the interaction between them was significant in both seasons. The lowest thrips mean the number was recorded in Goara x SA at 200ppm (2.69 thrips/ ten leaves) and Line 14 x SA at 200ppm (3.05 thrips/ ten leaves) in 2018/2019 and 2019/2020 seasons, respectively, with insignificant differences between each of them and Line $11 \mathrm{x}$ SA at 200ppm in both seasons, and with Line $11 \mathrm{x} \mathrm{SA}$ at 100ppm in the second season of the study. On the other hand, Entesar $1 \mathrm{x}$ control harboured the highest thrips infestation with 10.41 and 11.46 thrips/ ten leaves in the two seasons, respectively, followed insignificantly by Line $1 \mathrm{x}$ control in the second season. In most cases, the differences between SA treatments were significant in all cultivars. In agreement with these results, Dixit et al. (2018) who showed that foliar spray of SA at 250 mgl-1 at two or three times reduced the infestation of onion with thrips. In the same line, Hammam et al. (2019) found that the foliar application of marjoram plants with salicylic acid reduces the infestation of $T$. tabaci.

\section{3- Liriomyza trifolii:}

Depending on the mean number of mines due to L. trifolii per 10 leaves, two and three significant groups of effect were observed in 2018/2019 and 2019/2020 seasons, respectively. In the first season, Goara (4.21 mines/ 10 leaves) and Entesar 1 (4.29 mines/ 10 leaves) were in the lowest infested group, however, Line 11 (6.03 mines/ 10 leaves), Line 1 (6.31 mines/ 
10 leaves) and Line 14 (5.98 mines/ 10 leaves) were arranged in the highly infested group. In the second seasons, the lowest infested group included Goara (5.02 mines/ 10 leaves), Entesar 1 (5.93 mines/ 10 leaves) and Line 14 (6.08 mines/ 10 leaves), the highest infested group contained Line 1 (7.93 mines/ 10 leaves), while the third one consisted of Line 11 (6.36 mines/ 10 leaves) with insignificant differences with the previous two groups.

The results proved that the foliar application with SA reduced the mean number of mines due to L. trifolii comparing to control by $50 \%$ and $30 \%$ at $200 \mathrm{ppm}$ and $100 \mathrm{ppm}$, respectively, in the two seasons, also, no significant differences were found between $200 \mathrm{ppm}$ and 100ppm in the second season. SA at 200ppm, 100ppm, and control recorded 3.79, 4.77, and 7.53 mines/ 10 leaves, respectively, in the first season, and 4.54, 5.42, and 8.83 mines/ 10 leaves, respectively, in the second season.

The combination of Entesar $1 \mathrm{x} \mathrm{SA}$ at 200ppm recorded the lowest mean of 2.13 and 3.21 mines/ 10 leaves in the two seasons, respectively, followed insignificantly by Entesar 1 x SA at 100ppm, Goara x SA at 200ppm, Goara x SA at 100ppm and Line 14 x SA at 200ppm in 2019/2020 season. Meanwhile, Line $1 \mathrm{x}$ control and Entesar $1 \mathrm{x}$ control harboured the highest leafminer infestation in 2018/2019 and 2019/2020 seasons, respectively, with 9.49 and 9.77 mines/ 10 leaves, respectively, with insignificant difference between them in the second season. The present results are in harmony with those of El-Khawas (2012) who suggested that using elicitors as salicylic acid to induce resistance of pea plants against leafminer has been successful as one of the alternative pest management tools.

\section{Horticultural Data:}

Data in Table (3) revealed that the differences between pea cultivars and between SA treatments were significant in both seasons for all horticultural characters. Also, the interaction between pea cultivars and SA treatments were significant in both seasons for plant height and a number of pods/ plant, however, the interaction was significant in the first season only for the average weight of pod, total yield/ plant and total yield/ feddan (Table 4). It is clear that the differences between SA treatments varied according to the pea genotype in both seasons.

\section{Plant Height:}

The highest plant length was recorded in Line 11 with 98.29 and $94.71 \mathrm{~cm}$ in the two seasons, respectively, by insignificant differences with Line 14 in the first season, however, Entesar 1 recorded the lowest plant length with 51.11 and $51.47 \mathrm{~cm}$ in the two seasons, respectively (Table 3 ).

Data showed that foliar spray pea plants with salicylic acid significantly increased plant length in both seasons compared to control, by the insignificant difference between 200ppm and $100 \mathrm{ppm}$ in the first season. SA at 200ppm, 100ppm, and control recorded 80.27, 77.51, and $74.03 \mathrm{~cm}$, respectively, in the first season, and $79.71,74.35$, and $71.43 \mathrm{~cm}$, respectively, in the second season.

The maximum plant length was recorded in Line $11 \mathrm{x}$ SA at 200ppm $(102.80 \mathrm{~cm})$ and Line $14 \mathrm{x} \mathrm{SA}$ at $200 \mathrm{ppm}(104.40 \mathrm{~cm})$ in the two seasons, respectively, with an insignificant difference between them in the first season. However, the minimum plant length was recorded in Entesar 1 x control with 50.07 and $50.39 \mathrm{~cm}$ in the two seasons, respectively, followed insignificantly by the same cultivar with the two SA treatments in both seasons. The previous results were in partial agreement with these of Gad El-Hak et al. (2012) who showed that the foliar application by SA markedly affected pea plant height. Also, Ratushnyak et al. (2012) reported that SA application increased the plant height of the pea plant. 
Table 3: Effect of pea cultivars and foliar spray with salicylic acid on plant height and yield during 2018/2019 and 2019/2020 seasons.

\begin{tabular}{|c|c|c|c|c|c|c|c|c|c|c|}
\hline \multirow{2}{*}{ Main effect } & \multicolumn{2}{|c|}{ Plant Height (cm) } & \multicolumn{2}{|c|}{$\begin{array}{c}\text { Number of Pods/ } \\
\text { plant }\end{array}$} & \multicolumn{2}{|c|}{ Weight of pod (g) } & \multicolumn{2}{|c|}{ Total yield/plant $(\mathrm{g})$} & \multicolumn{2}{|c|}{$\begin{array}{l}\text { Total yield/ Fed. } \\
\text { (ton) }\end{array}$} \\
\hline & $\begin{array}{l}2018 / 19 \\
\text { season }\end{array}$ & $\begin{array}{l}2019 / 20 \\
\text { season }\end{array}$ & $\begin{array}{l}2018 / 19 \\
\text { season }\end{array}$ & $\begin{array}{l}2019 / 20 \\
\text { season }\end{array}$ & $\begin{array}{l}2018 / 19 \\
\text { season }\end{array}$ & $\begin{array}{l}2019 / 20 \\
\text { season }\end{array}$ & $\begin{array}{l}2018 / 19 \\
\text { season }\end{array}$ & $\begin{array}{l}2019 / 20 \\
\text { season }\end{array}$ & $\begin{array}{l}2018 / 19 \\
\text { season }\end{array}$ & $\begin{array}{l}2019 / 20 \\
\text { season }\end{array}$ \\
\hline \multicolumn{11}{|l|}{ Pea variety } \\
\hline Entesar 1 & $51.11 \mathrm{~d}$ & $51.47 \mathrm{e}$ & $8.60 \mathrm{e}$ & $8.04 \mathrm{e}$ & $11.76 \mathrm{a}$ & $11.96 \mathrm{a}$ & $101.19 \mathrm{~d}$ & $96.28 \mathrm{c}$ & $4.05 \mathrm{~d}$ & $3.85 \mathrm{c}$ \\
\hline Goara & $72.56 \mathrm{~b}$ & $71.62 \mathrm{c}$ & $20.16 \mathrm{c}$ & $20.36 \mathrm{c}$ & $7.84 \mathrm{c}$ & $7.81 \mathrm{~b}$ & $158.63 \mathrm{c}$ & $158.91 \mathrm{~b}$ & $6.35 \mathrm{c}$ & $6.36 \mathbf{b}$ \\
\hline Line 11 & $98.29 \mathrm{a}$ & $94.71 \mathrm{a}$ & $25.89 b$ & $25.30 \mathrm{~b}$ & $8.11 \mathrm{c}$ & $8.21 \mathrm{~b}$ & $210.21 \mathrm{~b}$ & $207.99 \mathrm{a}$ & $8.41 \mathrm{~b}$ & $8.32 \mathrm{a}$ \\
\hline Line 1 & $66.69 c$ & $66.62 \mathrm{~d}$ & $12.88 \mathrm{~d}$ & $12.14 \mathrm{~d}$ & $8.43 \mathrm{~b}$ & $8.52 \mathrm{~b}$ & $109.17 \mathrm{~d}$ & $103.94 \mathrm{c}$ & $4.37 \mathrm{~d}$ & $4.16 \mathrm{c}$ \\
\hline Line 14 & $97.69 \mathrm{a}$ & $91.38 \mathrm{~b}$ & $28.39 a$ & $26.94 a$ & $8.09 c$ & $8.26 \mathrm{~b}$ & $229.49 \mathrm{a}$ & $222.61 \mathrm{a}$ & $9.18 \mathrm{a}$ & $8.90 a$ \\
\hline F. value & 704.72 & 1737.54 & 1153.33 & 1134.26 & 1134.44 & 88.54 & 580.68 & 159.51 & 578.34 & 158.85 \\
\hline \multicolumn{11}{|l|}{ SA treatment } \\
\hline Salicylic 200 & $80.27 a$ & $79.71 \mathrm{a}$ & $19.88 \mathrm{a}$ & $19.78 \mathrm{a}$ & $9.11 \mathrm{a}$ & $9.15 \mathrm{a}$ & $174.81 \mathrm{a}$ & $173.51 \mathrm{a}$ & $6.99 a$ & $6.94 a$ \\
\hline Salicylic 100 & $77.51 \mathrm{a}$ & $74.35 \mathrm{~b}$ & $19.54 \mathrm{a}$ & $18.62 \mathbf{b}$ & $8.94 \mathrm{a}$ & $9.12 \mathrm{a}$ & $166.02 b$ & $160.81 \mathrm{a}$ & $6.64 \mathbf{b}$ & $6.43 \mathrm{a}$ \\
\hline Control & $74.03 \mathrm{~b}$ & $71.43 \mathrm{c}$ & $18.14 b$ & $17.26 \mathrm{c}$ & $8.49 \mathrm{~b}$ & $8.59 \mathrm{a}$ & $144.38 \mathrm{c}$ & $139.51 \mathrm{~b}$ & $5.78 \mathrm{c}$ & $5.58 \mathrm{~b}$ \\
\hline F. value & 39.99 & 147.66 & 44.55 & 72.72 & 69.29 & 5.82 & 163.45 & 33.20 & 165.14 & 33.20 \\
\hline
\end{tabular}

Means of among of each column followed by the same letter are not significantly different at the $5 \%$ level according toDuncan, s Multiple Range Test.

Table 4: Effect of the interaction between pea cultivars and spraying with salicylic acid on plant height and yield during 2018/2019 and 2019/2020 seasons.

\begin{tabular}{|c|c|c|c|c|c|c|c|c|c|c|c|}
\hline \multirow[b]{2}{*}{$\begin{array}{c}\text { Pea } \\
\text { variety }\end{array}$} & \multirow{2}{*}{$\begin{array}{c}\text { Salicylic } \\
\text { treatment }\end{array}$} & \multicolumn{2}{|c|}{ Plant Height (cm) } & \multicolumn{2}{|c|}{ Number of Pods/ plant } & \multicolumn{2}{|c|}{ Weight of pod (g) } & \multicolumn{2}{|c|}{ Total yield/ plant (g) } & \multicolumn{2}{|c|}{ Total yield/ Fed. (ton) } \\
\hline & & \begin{tabular}{|l|}
$2018 / 19$ \\
season
\end{tabular} & $\begin{array}{l}2019 / 20 \\
\text { season }\end{array}$ & $\begin{array}{l}2018 / 19 \\
\text { season }\end{array}$ & $\begin{array}{l}2019 / 20 \\
\text { season }\end{array}$ & $\begin{array}{l}2018 / 19 \\
\text { season }\end{array}$ & $\begin{array}{l}2019 / 20 \\
\text { season }\end{array}$ & $\begin{array}{l}2018 / 19 \\
\text { season }\end{array}$ & $\begin{array}{l}2019 / 20 \\
\text { season }\end{array}$ & $\begin{array}{l}2018 / 19 \\
\text { season }\end{array}$ & $\begin{array}{l}2019 / 20 \\
\text { season }\end{array}$ \\
\hline \multirow{3}{*}{ Entesar 1} & SA 200 & $52.73 \mathbf{i}$ & $52.07 \mathrm{k}$ & $9.92 \mathrm{~h}$ & $9.33 \mathbf{h}$ & $11.57 \mathbf{b}$ & $11.93 \mathbf{a}$ & $114.91 \mathbf{i}$ & $111.46 \mathbf{h i}$ & $4.60 \mathbf{i}$ & $4.46 \mathbf{h i}$ \\
\hline & SA 100 & $50.53 \mathbf{i}$ & $51.47 \mathbf{k}$ & $8.48 \mathbf{i}$ & $7.81 \mathbf{i}$ & $12.05 \mathbf{a}$ & $12.22 \mathbf{a}$ & 102.21 jk & $95.50 \mathbf{i j}$ & $4.09 \mathbf{j k}$ & $3.82 \mathrm{ij}$ \\
\hline & Control & $50.07 \mathbf{i}$ & $50.87 \mathbf{k}$ & $7.39 \mathbf{j}$ & $6.99 \mathbf{i}$ & $11.67 \mathbf{b}$ & $11.74 \mathbf{a}$ & 86.46 I & $81.87 \mathbf{j}$ & $3.46 I$ & $3.27 \mathbf{j}$ \\
\hline \multirow{3}{*}{ Goara } & SA 200 & $74.40 \mathrm{e}$ & $73.87 \mathbf{g}$ & $21.41 \mathrm{~d}$ & $22.99 \mathrm{c}$ & $8.17 \mathrm{~d}$ & $7.80 \mathrm{~cd}$ & $175.16 \mathrm{e}$ & 179.26 ef & $7.01 \mathrm{e}$ & 7.17 ef \\
\hline & SA 100 & 73.07 ef & $71.53 \mathbf{h}$ & $21.61 \mathrm{~d}$ & $20.96 \mathbf{d}$ & $7.65 f$ & 7.87 bcd & $165.51 \mathrm{f}$ & $164.47 \mathrm{f}$ & $6.62 \mathbf{f}$ & $6.58 \mathrm{f}$ \\
\hline & Control & $70.20 \mathrm{fg}$ & 69.47 hi & $17.47 \mathrm{e}$ & $17.12 \mathrm{e}$ & $7.70 \mathrm{f}$ & $7.77 \mathrm{~cd}$ & $135.21 \mathbf{g}$ & $132.99 \mathrm{~g}$ & $5.41 \mathrm{~g}$ & $5.32 \mathrm{~g}$ \\
\hline \multirow{3}{*}{ Line 11} & SA 200 & $102.80 \mathbf{a}$ & $99.67 \mathbf{b}$ & $25.28 \mathrm{c}$ & 25.69 b & $8.56 \mathrm{c}$ & $8.60 \mathrm{bc}$ & 216.59 bc & 221.13 abc & 8.66 bc & $8.85 \mathrm{abc}$ \\
\hline & SA 100 & 97.60 bc & $93.60 \mathrm{c}$ & 27.49 b & $26.43 \mathrm{ab}$ & $7.98 \mathrm{de}$ & 8.07 bcd & $219.66 \mathbf{b}$ & 212.77 bc & $8.79 \mathbf{b}$ & 8.51 bc \\
\hline & Control & $94.47 \mathrm{~cd}$ & $90.87 \mathbf{d}$ & $24.91 \mathrm{c}$ & $23.79 \mathrm{c}$ & 7.79 ef & 7.97 bcd & $194.37 \mathrm{~d}$ & $190.07 \mathrm{de}$ & $7.77 \mathrm{~d}$ & $7.60 \mathrm{de}$ \\
\hline \multirow{3}{*}{ Line 1} & SA 200 & $68.80 \mathrm{~g}$ & $68.53 \mathbf{i}$ & $14.32 \mathbf{f}$ & $13.63 \mathbf{f}$ & $8.71 \mathrm{c}$ & $8.80 \mathbf{b}$ & $124.97 \mathbf{h}$ & $119.95 \mathbf{g h}$ & $5.00 \mathrm{~h}$ & $4.80 \mathrm{gh}$ \\
\hline & SA 100 & $67.67 \mathbf{g}$ & $67.13 \mathbf{i}$ & $12.61 \mathrm{~g}$ & $11.81 \mathrm{~g}$ & $8.47 \mathrm{c}$ & 8.69 bc & $107.33 \mathbf{i j}$ & 102.98 hij & $4.29 \mathbf{i j}$ & 4.12 hij \\
\hline & Control & $63.60 \mathrm{~h}$ & $64.20 \mathbf{j}$ & $11.71 \mathrm{~g}$ & $10.99 \mathbf{g}$ & $8.10 \mathrm{~d}$ & 8.07 bcd & $95.20 \mathrm{k}$ & $88.89 \mathbf{j}$ & $3.81 \mathrm{k}$ & $3.56 \mathbf{j}$ \\
\hline \multirow{3}{*}{ Line 14} & SA 200 & $102.60 \mathrm{a}$ & $104.40 \mathrm{a}$ & $28.45 \mathrm{a}$ & $27.28 \mathbf{a}$ & $8.51 \mathrm{c}$ & $8.63 \mathbf{b c}$ & 242.44 a & 235.78 a & 9.70 a & $9.43 \mathbf{a}$ \\
\hline & SA 100 & 98.67 b & $88.00 \mathrm{e}$ & 27.49 b & $26.11 \mathbf{b}$ & $8.55 \mathrm{c}$ & 8.73 bc & $235.37 \mathbf{a}$ & $228.33 \mathrm{ab}$ & $9.41 \mathbf{a}$ & $9.13 \mathbf{a b}$ \\
\hline & Control & $91.80 \mathrm{~d}$ & $81.73 \mathrm{f}$ & $29.23 a$ & $27.44 \mathbf{a}$ & $7.20 \mathrm{~g}$ & $7.43 \mathrm{~d}$ & $210.65 c$ & 203.72 cd & $8.43 c$ & $8.15 \mathrm{~cd}$ \\
\hline \multicolumn{2}{|c|}{ F. value } & 2.62 & 33.16 & 19.15 & 14.97 & 16.85 & $1.09 \mathrm{NS}$ & 3.47 & $0.47 \mathrm{NS}$ & 3.49 & $0.47 \mathrm{~N}$ \\
\hline
\end{tabular}

Means of among of each column followed by the same letter are not significantly different at the $5 \%$ level according to Duncan, s Multiple Range Test.

\section{Number of Pods/ Plants:}

The maximum numbers of pods per plant of 28.39 and 26.94 pods/ plant in the two seasons, respectively were recorded in Line 14, however, the minimum numbers of 8.60 and 8.04 were recorded in Entesar 1 in the two seasons, respectively (Table 3). 
Also, numbers of pods increased significantly by the foliar spray pea plants with salicylic acid in both seasons compared to control, by the insignificant difference between 200ppm and 100ppm in the first season. SA at 200ppm, 100ppm, and control recorded 19.88, 19.54 , and 18.14 pods/ plant, respectively, in the first season, and 19.78, 18.62, and 17.26 pods/ plant, respectively, in the second season.

For combination between pea cultivars and SA treatment, Line $14 \mathrm{x}$ control recorded the highest numbers of 29.23 and 27.44 pods/ plant in the two seasons, respectively, with insignificant differences with Line $14 \mathrm{x}$ SA at 200ppm in both seasons, and with Line $11 \mathrm{x}$ SA at $100 \mathrm{ppm}$ in the second season (Table 4). Entesar $1 \mathrm{x}$ control gave the lowest mean number of 7.39 and 6.99 pods/ plant in the two seasons, respectively, followed insignificantly by Entesar $1 \mathrm{x} \mathrm{SA}$ at 100ppm in the second season. The previous results were in the same line with these of Murtaza et al. (2007) who showed that the four pea cultivars differed significantly in terms of numbers of pods per plant and the treatment with SA increased number of pods, also, they reported that the interaction was found non-significant between cultivars and SA concentrations.

\section{Average of Pod Weight:}

The maximum average of pod weight was recorded in Entesar 1 with 11.76 and $11.96 \mathrm{~g}$ in the two seasons, respectively, however, the lowest one was obtained from Goara with 7.84 and $7.81 \mathrm{~g}$ in the two seasons, respectively (Table 3). The differences between the last cultivar and Line 11 and Line 14 in the two seasons, and Line 1 in the second season were insignificant.

Also, the average of pod weight increased significantly by the foliar spray pea plants with salicylic acid in both seasons compared to control, by the insignificant difference between 200ppm and 100ppm in the first season. SA at 200ppm, 100ppm, and control recorded an average of pod weight of $9.11,8.94$, and $8.49 \mathrm{~g}$, respectively, in the first season, and $9.15,9.12$ and $8.59 \mathrm{~g}$, respectively, in the second season.

For combination between pea cultivars and SA treatment, the highest average of pod weight of 12.05 and $12.22 \mathrm{~g}$ were recorded in Entesar $1 \mathrm{x} \mathrm{SA}$ at 200ppm in the two seasons, respectively, followed insignificantly by Entesar1 x SA at 100ppm and Entesar1 x control in the second season. Line $14 \mathrm{x}$ control gave the lowest pod weight of 7.20 and $7.43 \mathrm{~g}$ in the two seasons, respectively, followed insignificantly by Goara in all SA treatments, Line $11 \mathrm{x} \mathrm{SA}$ at $100 \mathrm{ppm}$ and $\mathrm{x}$ control and Line $1 \mathrm{x}$ control in the second season only. In previous studies, Gad El-Hak et al. (2012) found that the pod weight was significantly increased by SA foliar application.

\section{Total Yield/ Plant:}

The highest total yield of green pods per plant was achieved from Line 14 by 229.49 and $222.61 \mathrm{~g} /$ plant in the two seasons, respectively, followed insignificantly by Line 11 in the second season, however, Entesar 1 recorded 101.19 and $96.28 \mathrm{~g} /$ plant as the lowest total yield per plant in the two years of the study, respectively.

Using SA as foliar application increased the total yield per plant in pea plant comparing to untreated (control) in both seasons. The difference between SA at 200ppm and at 100ppm was significant and insignificant in the two seasons, respectively. SA at 200ppm, 100ppm, and control recorded 174.81, 166.02, and $144.38 \mathrm{~g} /$ plant, respectively, in the first season, and $173.51,160.81$, and $139.51 \mathrm{~g}$, respectively, in the second season.

Concerning the combination between pea cultivars and SA treatments, the total yield per plant was achieved from Line $14 \mathrm{x}$ SA at 200ppm with 242.44 and $235.78 \mathrm{~g}$ in the two seasons, respectively, followed insignificantly by Line $14 \mathrm{x} \mathrm{SA}$ at 100ppm in both seasons. The lowest total yield per plant was recorded in Entesar $1 \mathrm{x}$ control with 86.46 and $81.87 \mathrm{~g}$ in the two seasons, respectively, followed insignificantly by Entesar $1 \mathrm{x}$ SA at 100ppm, Line $1 \mathrm{x}$ SA at 100ppm and Line $1 \mathrm{x}$ control in the second season. El-Saadony et al. (2017) found that 
spraying pea plants with salicylic acid at (100ppm) had a positive significant effect in yield.

\section{Total Green Pods Yield/ Feddan:}

The highest green pods yield per feddan was achieved from Line 14 with 9.18 and 8.90 tons/ fed. in 2018/2019 and 2019/2020 seasons, respectively in bar with Line 11 (8.32 tons/ fed.) in the second season.

The feddan yield increased by about 1.21 to 1.36 tons in case of foliar application of SA at $200 \mathrm{ppm}$, and by about 0.85 to 0.85 tons in case of foliar application of SA at $100 \mathrm{ppm}$ compared to control. SA at 200ppm, 100ppm, and control recorded 6.99, 6.64, and 5.78 tons/ fed., respectively, in the first season, and 6.94, 6.43, and 5.58 tons/ fed., respectively, in the second season.

The highest yield per feddan was achieved from Line $14 \mathrm{x}$ SA at 200ppm with 9.70 and 9.43 tons/ fed. in the two seasons, respectively, followed insignificantly by Line $14 \mathrm{x} \mathrm{SA}$ at $100 \mathrm{ppm}$ in both seasons. The lowest total yield per feddan was recorded in Entesar $1 \mathrm{x}$ control with 3.46 and 3.27 tons/ fed. in the two seasons, respectively, followed insignificantly by Entesar 1 x SA at 100ppm, Line $1 \mathrm{x}$ SA at 100ppm and Line $1 \mathrm{x}$ control in the second season. The present results are in agreement with Gad El-Hak et al. (2012)

\section{CONCLUSION}

Our results indicated that the use of salicylic acid as foliar application reduced the populations of Aphis craccivora, Thrips tabaci and Liriomyza trifolii on all pea cultivars adopted. Also, salicylic acid enhanced plant growth and maximized yield per feddan. The effect of SA application on studied insect pests infestation varied from pea variety to other, this means that the SA effect may depend on pea genotype. The same was obtained on plant height and yield.

\section{REFERENCES}

Dixit, S.; A.K. Dubey and H.V. Dube (2018). Studies on the efficiency of salicylic acid (SA) as foliar spray on growth, yield and yield components of onion (Allium cepa L.). International Journal of Advance Biology Research.. 8 (2): 238-240.

Elhamahmy, M.A.M.; M.F. Mahmoud and T.Y. Bayoumi (2016). The effect of applying exogenous salicylic acid on aphid infection and its influence on histo-physiological traits and thermal imaging of canola. Cercetări Agronomice în Moldova. Vol. XLIX, No. 2 (166) / 2016: 67-85

El-Khawas, S.A. (2012). Priming Pisum sativum with salicylic acid against the leafminer Liriomyza trifolii. African Journal of Agricultural Research. 7(34): 4731-4737.

El-Roby, A.M.S. (2016). Seasonal activity of certain insect pests on green pea at Giza Governorate, Egypt. Egyptian Academic Journal of Biological Sciences, (A. Entomology) Vol. 9(4): 163-171.

El-Saadony, F.M.; D.A.S. Nawar and H.G. Zyada (2017). Effect of foliar application with salicylic acid, garlic extract and proline on growth, yield and leaf anatomy of pea (Pisum sativum L.) grown under drought. Middle East Journal of Applied Science, 7(3): 633-650.

El-Solimany, E.A. (2008). Ecological studies on the main pests and their natural enemies associated with some legume vegetables in Upper Egypt. M.Sc. Thesis, Fac. Agric. Minia Univ. pp. 185.

Gad El-Hak, S.H.; A.M. Ahmed and Y.M.M. Moustafa (2012). Effect of foliar application with two antioxidants and humic acid on growth, yield and yield components of peas (Pisum sativum L.). Journal of Horticultural Science \& Ornamental Plants. 4 (3): 318-328.

Gomez, K.A. and A.A. Gomez (1984). Statistical Procedures for Agricultural Research, 2nd 
Ed. A. John Wiley Intersci. p. 130-240.

Hammam, K.A.; A.M.S. EL-Roby and M.I. Ammar (2019). Impact of fertilization by using some phenolic compounds and humic acid on marjoram plants susceptibility to insects and mite infestation and plant features. Egyptian Journal of Agricultural Research, 97 (1): 187-202.

Hassan, A.M.; O.A. Zaghloul; N.A. El-sayed; N.A. Hassan and R.S. Ammar (2016). Dynamical seasonal fluctuations of the prevailing insect-pests on faba bean and garden pea plantations at Alexandria Governorate, Egypt. Alexandria Science Exchange Journal. 37(4): 669-678.

Hussein, M.M.; N.H.M. El-Gereadly and M. El-Desuki (2006). Role of puterscine in resistance to salinity of pea plants (Pisum sativum L.). Journal of Applied Science Research, 2(9): 598-604.

Kogan, M. and J. Paxton (1983). Natural inducers of plant resistance to insects, in P.A .Hedm (ed,), plant Resistance to Insects, pp. 153- 171. American Chemical Society, Washington, D. C.

Mahmoud, F.M. and H.M. Mahfouz (2015). Effects of salicylic acid elicitor against aphids on wheat and detection of infestation using infrared thermal imaging technique in Ismailia, Egyptian Pesticide Phytomedicine, (Belgrade), 30(2), 2015, 91-97.

Mony, F.T.Z.; M.S. Ali; Md.N. Islam; S. Choudhury and M.S. Hossain (2017). Effect of salicylic acid and varieties on incidence of aphid and yield Of mustard. Journal of Multidisciplinary Engineering Science Studies, (JMESS). 3(2): 1331-1340.

Murtaza, G.; R. Asghar; S. Ahmad and S. Abdul-Majid (2007). The yield and yield components of pea (Pisum sativum 1.) As influenced by salicylic acid. Pakistan Journal of Botany, 39(2): 551-559.

Ratushnyak, A.Y.; A.A. Ratushnyak; M.G. Andreeva; A.R. Kayumov; M.I. Bogachev and M.V. Trushin (2012). Effect of lead and salicylic acid on some plant growth parameters in Pisum sativum L. World Applied Science Journal, 19 (8): 1157-1159.

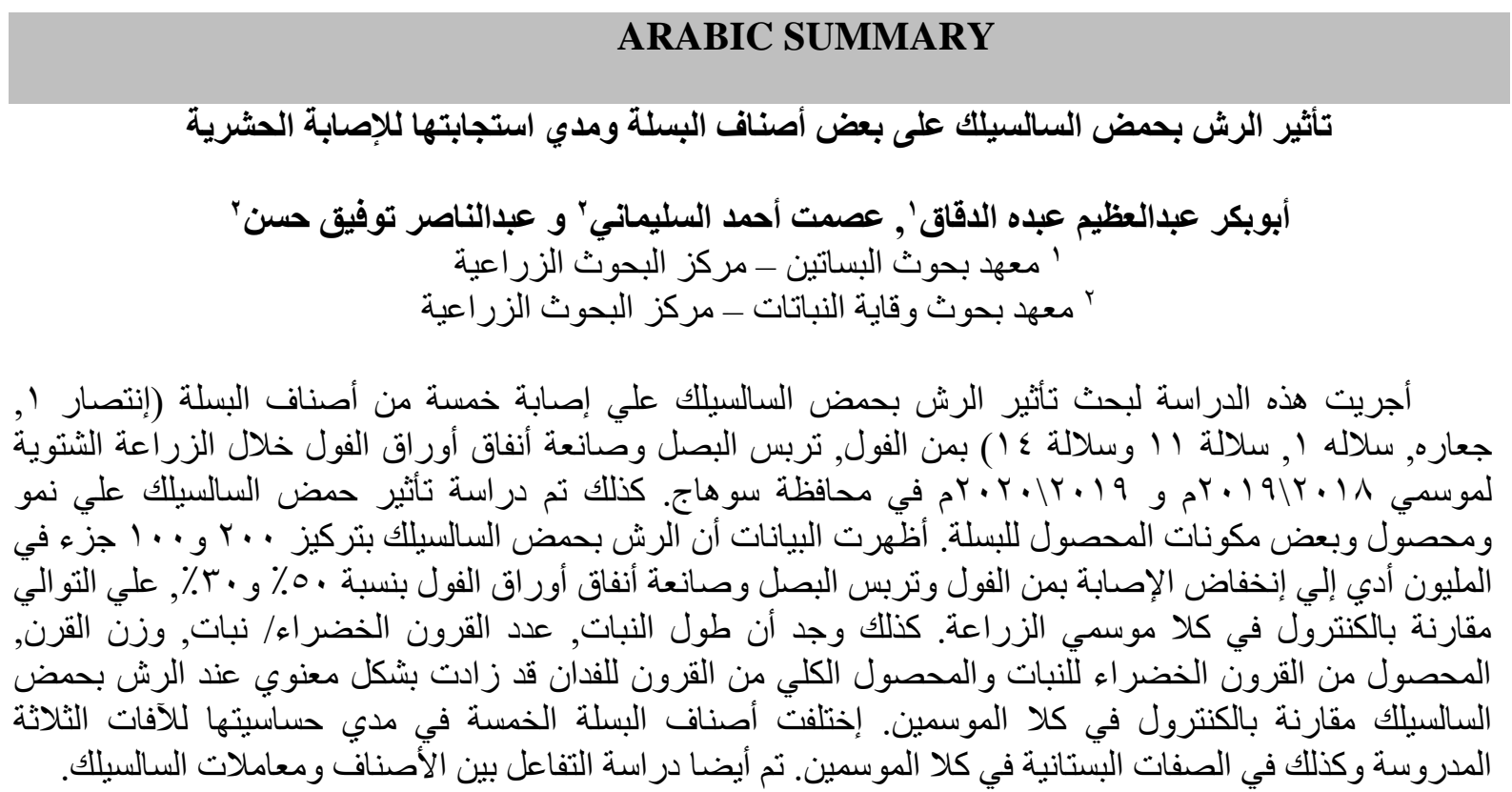

